\title{
Biphasic malignant mesothelioma of the testis: Case report
}

\section{Testisin bifazik malign mezotelyoması: Olgu sunumu}

\author{
Coban $\mathrm{G}^{1}$, Unver $\mathrm{N}^{1}$, Kiziltan $\mathbb{H S}^{2}$, Armagan $\mathrm{A}^{3}$, Gucin $\mathrm{Z}^{1}$
}

\author{
Bezmialem Vakıf University, Pathology Department, ${ }^{2}$ Bezmialem Vakıf University, Radiation Oncology Department, 3 Medical Park Bahcelievler \\ Hospital, Urology Department, Istanbul \\ Corresponding author: Ganime Coban, Bezmialem Vakif University „Faculty of Medicine, Department of Pathology, Fatih; Istanbul \\ E-mail: drgcoban@hotmail.com \\ Received/Accepted: October 04, 2016 / January 09, 2017
}

Conflict of interest: There is not a conflict of interest.

\section{SUMMARY}

Malign Mesothelioma is a tumor originating from serous lining. Although it was most commonly seen in pleura, it can also located in other areas such as peritoneal and rarely paratesticular region. Our case presented with pain and swelling in the right scrotal region. Tumor markers were within normal limits (Alpha Fetoprotein (AFP), Beta Human Chorionic Gonadotropin (Beta-HCG) and alkaline phosphatas Ultrasonographic examination revealed that nodular masses which infiltrating tunica vaginalis. The largest diameter of the nodules was $5 \mathrm{~cm}$. Radical orchiectomy was performed because of the tunica vaginalis invasion and tumor extensity. The patient was diagnosed as mesothelioma with morphological and immunohistochemical examination. Addition to classical epithelial component, accompanying sarcomatous component $(\% 10)$ led us to give the biphasic mesothelioma diagnosis-Mesothelium originated other lesions, adenocarcinoma of the rete testis, papillary serous neoplasm of testis and epididymis, metastatic adenocarcinomas and germ cell tumors of testis such as seminoma and embriyonal carcinoma should be considered in the differential diagnosis. The patients with widespread tumor nodules and having normal tumor markers mesothelial originated tumors should be taken into differantial diagnosis

Keywords: Orchiectomy, Testis, Pathology, Biphasic, Malignant Mesothelioma

\section{ÖZET}

Malign Mezotelyoma, seröz yüzeylerden kaynaklanan bir tümördür. En sık plevrada görülmekte olup periton ve nadiren paratestiküler bölge de diğer yerleșim yerlerindendir. Olgumuz sağ skrotal bölgede ağrı ve şișlik şikayeti ile başvurmuștu. Tümör belirteçleri (Alfa Fetoprotein, Beta HCG, Alkalan Fosfataz vb.) normal sinırlardaydı. Ultrasonografide tunika vaginalis invazyonu gösteren nodüler kitleleri mevcuttu. Nodüllerin en büyüğü $5 \mathrm{~cm}$ çapındaydı. Tunika vaginalis invazyonu ve yaygın tümör olması nedeniyle orşiektomi yapıldı. Morfolojik ve immünohistokimyasal olarak mezotelyoma tanısı kondu. Ayrıca klasik epitelyal komponente \%10 sarkomatöz alanın da eşlik etmesi ile Bifazik Mezotelyoma tanısı verildi. Ayırıcı tanıda mezotelyum kaynaklı diğer lezyonlar, rete testis ve epididimin adenokarsinomu, metastatik adenokarsinomlar ve seminom ve embriyonel karsinom gibi testisin germ hücreli tümörleri düşünülmelidir. Tümör belirteçleri normal, yaygın tümör nodülleri olan vakalarda mezotelyal orjinli tümörler de düşünülmelidir. 


\section{INTRODUCTION}

Malign mesothelioma (MM) is a rare and aggressive tumor. The most common locations of the tumor are pleura, peritoneum, pericardium and tunica vaginalis of testis, according to the order of frequency. Paratesticular mesothelioma (PMM), which constitutes $0,3-1,4 \%$ of all mesothelioma cases, has no typical clinical and radiological findings. Histopathological and immunohistochemical evaluations are the principles of the diagnosis. ${ }^{1}$ In this we presented this rare case accompanied with the literature data.

\section{CASE REPORT}

62-year old male patient presented with the complaints of pain and swelling in the right scrotal region. Hernia and hydrocele operations were in clinical history which happened two years ago performed at different center and we could not reach to pathological examination. Testicular tumor markers (Alpha Fetoprotein (AFP), Beta Human Chorionic Gonadotropin (Beta-HCG) and alkaline phosphatas(ALP)) of the patient were within the normal range. Scrotal ultrasonographic examination revealed a nodular mass which $5 \mathrm{~cm}$ in diameter, continues with tunica vaginalis and reaches to testis. Right radical orchiectomy was performed for diagnosis and treatment.

On macroscopic examination, a tumoral mass which continues with tunica vaginalis and pushes testis aside with a clear interface was detected. Tumor had 3 nodules, the biggest and the smallest being $5 \times 4 \times 2.6 \mathrm{~cm}$ and $1.7 \times 0.8 \times 0.5 \mathrm{~cm}$, respectively. In addition, thickening in tunica and small nodular appearances were also present. Cut surface was off-white and yellow in colour having patchy necrotic areas. Tumor appeared to invade epididymis and the initial part of spermatic cord (Figure 1a).

On microscopic examination, tumor was composed of tubular, papillary and solid structures in a large area forming epithelial component and sarcomatoid component forming fascicles in a focal area $(\% 10)$. In the epithelial component the tumoral cells had prominent nucleoli and wide eosinophilic cytoplasm (Figure $1 \mathrm{~b}, \mathrm{c}, \mathrm{d})$. The sarcomatous cells were spindle shaped. MM germ cell tumor of testis, adenocarcinoma of the rete testis and serous papillary tumor were considered in histopathological differential diagnosis. In immunohistochemical examinations, positive immunoreactivity with vimentin, calretinin, WT1 and mesothelin was found in tumor cells (Figure 2). It is quite difficult to distinguish MM from papillary serous neoplasm histopathologically. The results of immunhistochemical stainings performed for differentiation were positive for CK5/6 and CK7, negative for MOC31 and TAG72. Biphasic MM diagnosis was made according to histopathological and immunohistochemical findings. The patient was scheduled for radiotherapy. The radiotherapy aplicated to scrotal region with $4 \times 4 \mathrm{~cm}$ field with IMRT (Intensive Modulated Radiation Therapy) method using Tomotherapy device. Positron emission tomography performed for staging revealed no evidence for malignancy on other sites of body. During 13-months follow-up period from the time of diagnosis, no clinical or pathological finding has been detected. 

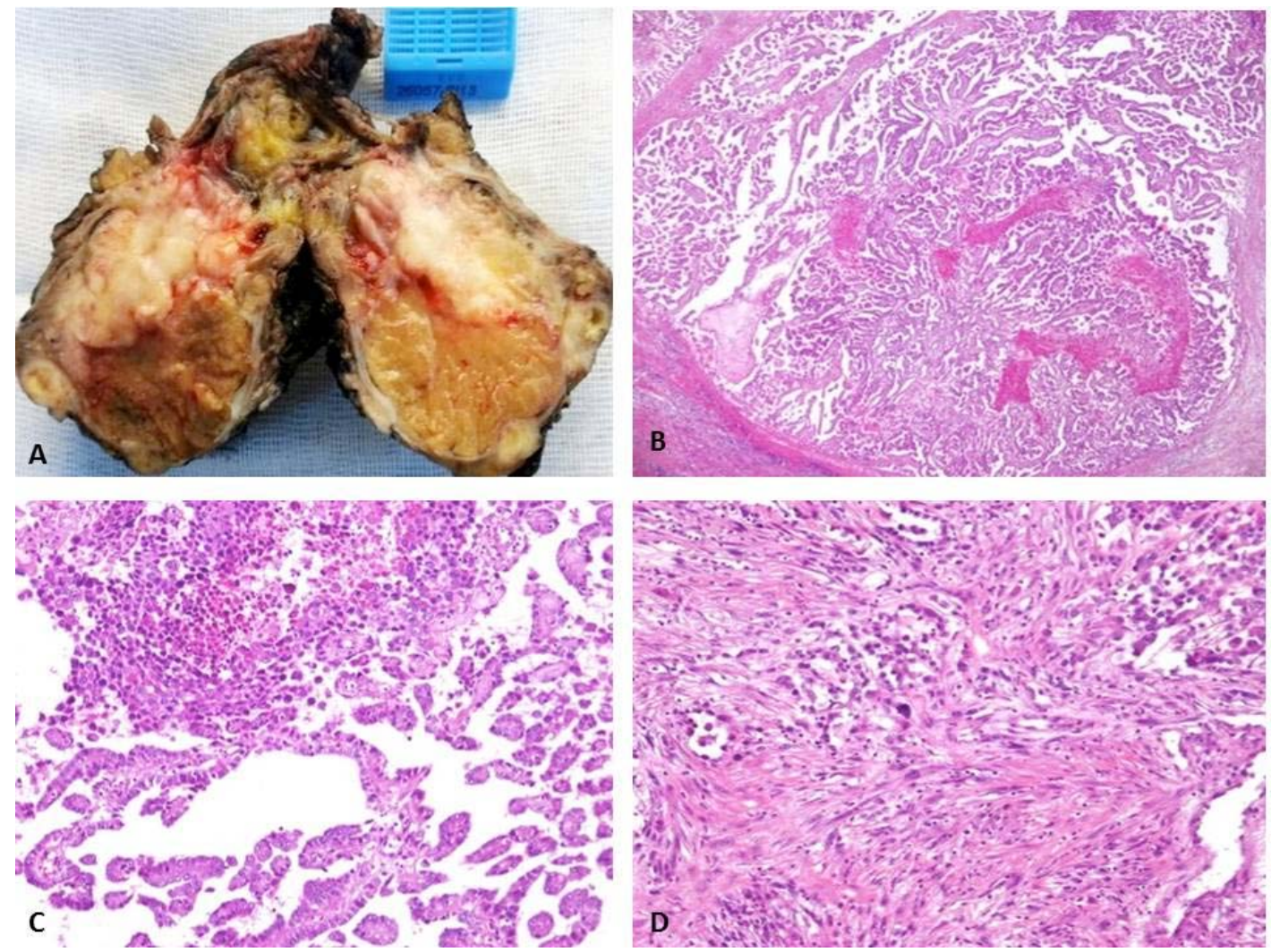

Figure 1: A.Macroscopic appearance of the beige colored tumor showing nodulation and a thickened tunica. B,C. Tumor consisting of papillary structures (HEX100). D.Focal areas in the tumor consisting of spindle cells (HEX200).
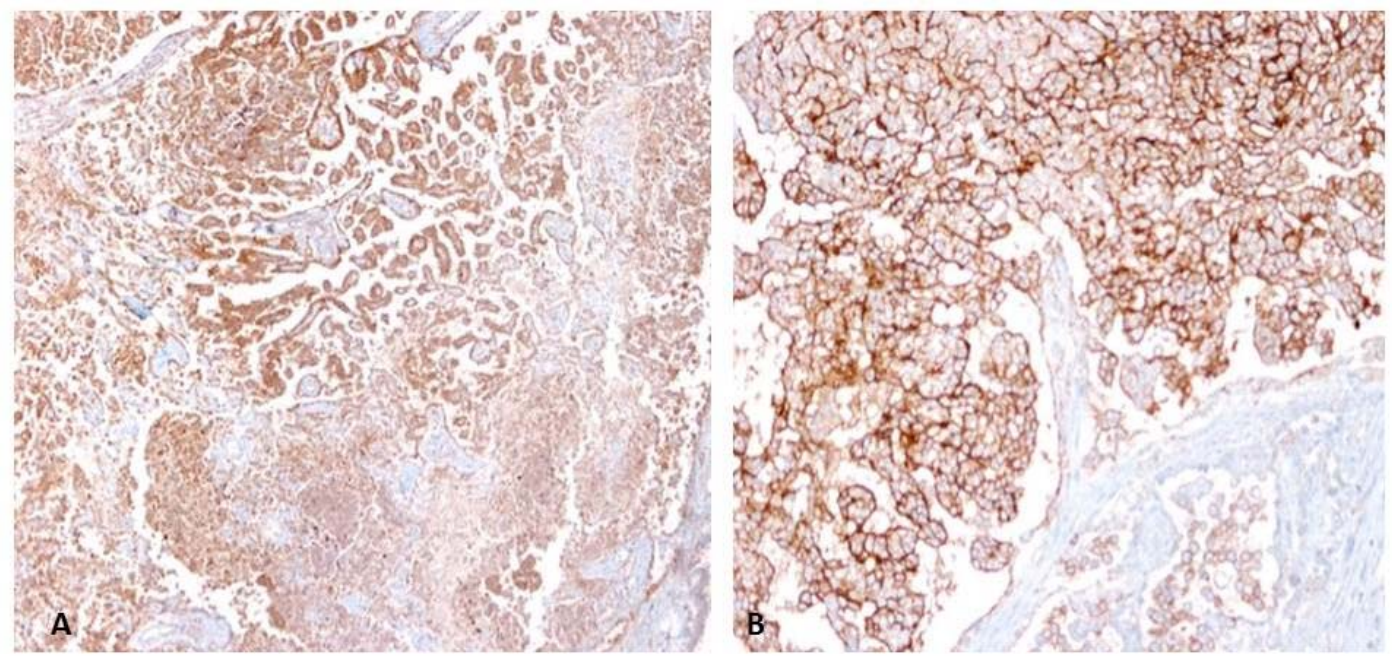

Figure 2: A,B.Diffuse immunostaining of the neoplastic cells by calretinin (x100) and mesothelin antibody (x200). 


\section{DISCUSSION}

MM originates from pleura, peritoneum, pericardium and tunica vaginalis, according to the order of frequency. PMM is rather rare. It is mostly seen in the patients aged 12-76 years ${ }^{1}$.

It has been suggested that asbestos (most common), trauma, herniography and chronic hydrocele play role in the etiology of testicular mesothelioma. MM may also occur in the absence of predisposing factors. History of our patient revealed no asbestos exposure, while he had undergone hydrocele operation and herniography 2 years ago.

The clinical manifestations of PMM are nonspecific. Testicular pain, swelling and scrotal stretch may be observed ${ }^{2}$. Testicular tumor markers are within normal range. Most of PMM originate from tunica vaginalis, while it may less frequently originate from spermatic cord and epididymis ${ }^{3}$. Macroscopically, MM may invade other paratesticular regions such as testis, epididymis, rete testis and spermatic cord ${ }^{4}$. PMM are usually unilateral, but it may rarely be bilateral ${ }^{5}$. It is difficult to make the diagnosis of mesothelioma in a patient with testicular mass unless performing histopathological examination.

Microscopically, MM may be composed of sarcomatoid component and papillary, tubulopapillary or solid pattern forming component. The most common types of MM are epithelial and biphasic, sarcomatoid type is being rather rare. Mesothelium originated other lesions (mesothelial hyperplasia, adenomatoid tumor), adenocarcinoma of the rete testis, papillary serous neoplasm of testis and epididymis, metastatic adenocarcinomas and germ cell tumors of testis such as seminoma and embriyonal carcinoma should be considered in the differential diagnosis ${ }^{3}$. It may be especially difficult to differentiate it from papillary serous neoplasm. In serous tumors, however, papillae is thicker, psammoma bodies are more prominent and they have stratification and budding. Papillary serous tumors were as immunohistochemically express CEA and BerEp4, while MM is usually negative. In addition to these properties, calretinin and thrombomodulin expressions may be present in papillary serous tumors ${ }^{6}$. Adenocarcinoma of the rete testis resides at rete testis zones and hilus macroscopically, but it is hard to distinguish from PMM when they invade tunica. Both tumor forms show tubular and papillary formations microscopically. The adenocarcinoma of rete testis shows sertoliform and retiform patterns. Immunhistochemical examination is limited at diagnosis of these tumors and they can be stained at low level with WT1, calretinin and CEA. It is important to show the tumor's localization and transition and epithelial dysplasia for differentiation. Sampling of whole rete testis can be necessary to show the between tumor and rete testis connection. Whole rete testis of our case was sampled and no epithelial dysplasia was seen.

Negativity of immunhistochemical markers like placental alkaline phospatase (PLAP), Octamer binding transcription factor 4 (OCT 4), sal-like protein 4(SAL-4), CD30 and absence of intratubular germ cell neoplasia at surrounding area are important for differentiating PMM from germ cell tumors of testis such as seminoma and embryonal carcinoma ${ }^{4}$.

The main treatment is surgery, postoperative radiotherapy and/or chemotherapy may be applied. Recurrence and distant metastasis may be seen despite radical orchiectomy and adjuvant treatment (chemotherapy and/or radiotherapy).

The mean life expectancy is 23 months $^{2}$. No recurrence or metastasis occurred in this case during postoperative 13 months follow-up period.

In conclusion, PMM is a rare pathology having nonspecific symptoms, clinical laboratory and radiological findings. Moreover it may develop in the absence of the history of asbestos exposure, hydrocele, trauma and herniography which are known predisposing factors. If tumor markers within normal range, nodular appearance on USG and especially in older ages non- germ cell tumors as seen in this case should keep in mind.

\section{REFERENCES}

1. C W Mak, MD, T Cheng, MD, S S Chuang, $\mathrm{MD}, \mathrm{R} \mathrm{H} \mathrm{Wu}, \mathrm{MD}, \mathrm{C} \mathrm{K}$ Chou, MD and J M Chang, MD. Malignant mesothelioma of the tunica vaginalis testis. The British of Radiology, 2004;77: 780-781.

2. Esen T, Acar O, Peker K, Sarman K, Musaoğlu A and Tefekli A. Malignant Mesothelioma of the Tunica Vaginalis: Presenting with Intermittent Scrotal Pain and Hydrocele. Case Reports in Medicine Volume 2012, Article ID 189170.

3. Varun Rajan, R. Nandhakumar, $S$ Shanmugasundaram, R Ravi, S Natarajan, G Mohan, P M Nanjundappan. Paratesticular Malignant Mesothelioma - A Rare Case Presentation. Indian J Surg 2013;75:174-176.

4. Seble S. C, MD, Chen-Chin S, MD. Malignant Mesothelioma of the Tunica Vaginalis Testis Diagnostic Studies and Differential diagnosis. Arch Pathol Lab Med 2012;136 (1):113-117. 
5. Chen JL, Hsu YH. Malignant mesothelioma of the tunica vaginalis testis: a case report and literature review. Kaohsiung $\mathrm{J}$ Med Sci. 2009;25(2):77-81.

6. Amin MB. Selected other problematic testicular and paratesticular lesions: rete testis neoplasms and pseudotumours, mesothelial lesions and secondary tumours. Mod Pathol. 2005;18(2):131-145. 